\title{
A multilingual church leader for a multilingual world: A case study
}

\begin{abstract}
Author:
Susan Coetzee-Van Rooy ${ }^{1}$

\section{Affiliation:}

${ }^{1}$ Faculty of Humanities, North-West University, Vaal Triangle Campus, South Africa

\section{Correspondence to:} Susan Coetzee-Van Rooy

Email:

susan.coetzeevanrooy@nwu. ac.za

\section{Postal address:}

PO Box 1174, Vanderbijlpark 1900 , South Africa

\section{Dates:}

Received: 17 July 2014 Accepted: 29 Oct. 2014 Published: 19 Dec. 2014

\section{How to cite this article:} Coetzee-Van Rooy, S., 2014, 'A multilingual church leader for a multilingual world: A case study', In die Skriflig 48(2), Art. \#1865, 12 pages. http://dx.doi.org/10.4102/ ids.v48i2.1865
\end{abstract}

\section{Copyright:}

C) 2014. The Authors.

Licensee: AOSIS

OpenJournals. This work is licensed under the Creative Commons Attribution License.

\section{Read online:}

Scan this $Q R$ code with your smart phone or mobile device to read online.
The world is increasingly becoming more multilingual. South Africa has a long history of multilingualism. In the post-1994 South Africa, integrated organisations like churches where individual and organisational multilingualism are prevalent are growing. Previous and current studies of language use in integrated congregations indicate that multilingualism is a challenge to church leaders. In post-1994 integrated churches in South Africa where multilingualism is prevalent, congregations can foster innovative functional multilingual arrangements to benefit their ministry. However, evidence from research indicates that church leaders struggle to make functional multilingual arrangements and often monolingual English services are offered instead. The multilingual abilities and willingness of church leaders to foster functional multilingual arrangements for their churches is a core factor in this matter. The ability of church leaders to foster effective communication in a linguistically complex setting is important in the general interest of successful evangelisation. In this article, a case study approach is used to explore the latent potential present in the multilingual repertoire of a church leader to foster a functionally multilingual context in his congregation. The multilingual repertoire of a church leader is described and related to his perceptions of its usefulness to ministry as a profession. Descriptions of this nature are important in a context where the abilities and willingness of ministers to foster multilingual congregations have been acknowledged as core factors that determine the success of implementation. Improving the understanding of the nature of the multilingual repertoires of ministers would enable educators of ministers to ascertain how these resources could be activated to enhance ministry in the post-1994 South Africa. The main findings from this case study are that the multilingual repertoire of this church leader is unique because of its scope and the exceptional abilities of this church leader in Southern Sotho; and the church leader displays enhanced levels of metalinguistic awareness. Based on the perceptions of the participant, the multilingual abilities of this church leader is related to his ministry in specific ways, viz. it is part of his general calling to become a church leader; it is part of his additional calling to be a bridge-builder between white and black people in his community; it enables him to craft a specific personal communication strategy where he uses his Southern Sotho abilities to start conversations with all people, that provide an entrance point for him to begin relationships, so that he could invite them into his ministry; and it is a valuable resource that enables him to minister effectively. From the description of this exceptional case study, it is possible to begin to consider the implications of the multilingual needs of a multilingual world for ministry in integrated churches in South Africa. The findings are useful because they provide a starting point for the reconsideration and exploration of implications for theological education and language policy matters in the domain of the church today.

'n Meertalige kerkleier vir 'n meertalige wêreld: 'n Gevallestudie. Die wêreld word toenemend meertalig. Suid-Afrika het 'n lang geskiedenis van meertaligheid. Geïntegreerde organisasies soos kerke waar individuele en institusionele meertaligheid die botoon voer, word al hoe meer in die post1994 Suid-Afrika. Bevindings in vorige en onlangse studies wat op taalgebruik in die geïntegreerde gemeentes fokus, dui aan dat meertaligheid ' $n$ uitdaging vir kerkleiers is. In die geïntegreerde kerke in die post-1994 Suid-Afrika waar meertaligheid prominent is, is daar die moontlikheid om innoverende funksioneel-meertalige oplossings te vind wat die sukses van evangelisasie kan ondersteun. Ongelukkig dui bevindings wat uit navorsing vloei aan dat kerkleiers sukkel om funksioneel-meertalige reëlings te implementeer en dat daar dikwels eentalige Engelse dienste aangebied word. Die meertalige vermoëns en die bereidwilligheid van kerkleiers om funksioneel-meertalige reëlings in gemeentes te vestig, is as 'n kernfaktor in hierdie stryd bewys. Die vermoëns van kerkleiers om effektiewe kommunikasie te vestig in kontekste wat taalgewys kompleks is, is in die algemene belang van suksesvolle evangelisasie belangrik. In hierdie aritkel word die benadering van 'n gevallestudie gebruik om die sluimerende potensiaal in die meertalige repertoire van een kerkleier te ondersoek, naamlik om funksioneel-meertalige reëlings in 'n gemeente te implementeer. Die meertalige repertoire van die kerkleier word beskryf en in verband met sy persepsies van die bruikbaarheid van meertaligheid vir sy professie as kerkleier gebring. Beskrywings van hierdie aard is belangrik in 'n konteks waar die vermoëns en bereidwilligheid van kerkleiers as deurslaggewende faktore vir die sukses van die implementering van meertaligheid in gemeentes aangedui is. Die verdieping van insig in die verstaan van die aard van meertalige repertoires van kerkleiers kan 'n bydrae tot die opleiding van kerkleiers maak deurdat dit kan help bepaal hoe hierdie bronne in die post1994 Suid-Afrika geaktiveer kan word. Die hoofbevindings van hierdie gevallestudie is dat die meertalige repertoire van hierdie kerkleier uniek is vanweë die omvang en die uitsonderlike vermoëns van hierdie kerkleier om Suid-Sotho te gebruik; en die kerkleier demonstreer verhoogde vlakke van metalinguistiese bewustheid. Die persepsies van die deelnemer in hierdie studie dui aan dat hy sy meertalige vermoëns op baie spesifieke maniere tot sy roeping as kerkleier verbind, naamlik dat dit deel van sy algemene roeping is om 'n kerkleier te word; dit is deel van sy bykomende roeping om brûe tussen wit en swart mense in sy gemeenskap te bou; dit stel hom in staat om 'n baie spesifieke kommunikasiestrategie te skep waar hy sy vermoëns in Suid-Sotho gebruik om gesprekke met alle mense te begin. Dit gee hom 'n aanknopingspunt om verhoudings te begin wat daartoe kan lei dat hy mense na sy gemeente nooi; en na sy mening is dit is ' $n$ waardevolle bron wat sy evangelisasie meer effektief maak. Die beskrywing van die meertalige repertoire in hierdie uitsonderlike gevallestudie lei tot meer insig in die meertalige vereistes wat 'n meertalige wêreld aan kerkleiers van geïntegreerde kerke in Suid-Afrika stel. Die bevindings is bruikbaar, omdat dit ' $n$ basis is waarvandaan die implikasies vir teologiese opleiding en taalbeleidsake in die kerk as domein heroorweeg en verder ondersoek kan word. 


\section{Introduction}

Multilingualism is regarded as the 'new linguistic dispensation' (Aronin \& Singleton 2008:1; 2012) in the world today and its development is propelled by globalisation (Aronin \& Singleton 2008:1). At the local level, the multilingual history as well as the current multilingual nature of the South African society is acknowledged widely by scholars (Banda 2009; Deumert 2010; Dyers 2008a; 2008b; Ndlangamandla 2010; Prah 2010; Schneider 2007; Slabbert \& Finlayson 2000).

In post-1994 South Africa, integrated congregations are growing due to the demographic changes in urban areas and 'as a result people are increasingly drawn into ... multilingual settings' (Venter 1998:28). The multilingual nature of the current South African society poses potential challenges to church leaders. The main finding in a study of language preference in 60 integrated congregations is that, 'language was seen as the most prominent marker of diversity by far, and was also perceived to be the most problematic' (ibid:29). As a result of the problematic nature of multilingualism in these congregations, 'most congregations preferred monolingual sermons' (ibid:31), and 'the language of preference was usually English' (ibid:31). Similarly, Adams (2014) recently finds that English is used in the black Pentecostal charismatic church, despite the multilingual nature of the church leadership and members of the congregation.

Amongst the factors that limit the use of languages other than English in the integrated congregations that Venter (1998:33) studies, is the reluctance on the part of the congregational leadership to engage with the challenges related to the multilingualism present in their congregations. Venter (1998:34) finds that church leadership is the one factor that has the potential to support the use of languages other than English in these congregations. This is also true for the findings reported by Adams (2014). She notes that members of the church leadership in her study are multilingual and would potentially be able to conduct services in more than one language. Despite the multilingual abilities of the church leaders, English is mainly used.

The ability of church leaders to foster effective communication in a linguistically complex setting is important in the general interest of successful evangelisation. It is beyond the scope of this article to provide a comprehensive discussion of the complex relationships between ministry (or missionary work) and language preferences. In his overview of the role of the missionaries in language development in South Africa, Alexander (1989:13-14) highlights the two-pronged influence from this group on language preferences in religious contexts. On the one hand, 'their [the missionaries'] avowed aim was to assimilate their "wards" into the "Western Christian Civilisation" which they genuinely believed was superior to anything that Africans had ever produced' (ibid:15). This project was accompanied by the establishment of English mission schools where a small elite group of black South Africans was acculturated into the western culture which they distributed further as preachers and teachers (ibid:16). The role of English as instrument in colonisation and the spread of Christianity has recently been critised by scholars like Pennycook (2005).

On the other hand, missionaries also played a role in the development of indigenous languages, summarised as follows by Alexander (1989):

... the need and desire to spread the gospel among the heathen made it necessary to reduce the indigenous languages to writing and to teach these written languages as widely as possible (p. 16).

The contributions of missionaries in South Africa towards the development of indigenous languages as instruments of evangelisation are well-described (Doke 1939; 1959). For example, Doke (1959:1) refers to the 'unrepayable debt' that the Bantu languages in South Africa owe the missionaries for their efforts to codify the indigenous languages for this purpose.

The tension between the use of English and the use of indigenous languages in congregations is therefore a concern with a long history which is probably exacerbated in an increasingly multilingual and urbanising world. It is not the aim of this article to prescribe rules for the use of English or indigenous languages in integrated congregations today. In general, the ability to communicate effectively via the selection of languages in congregations is an important issue in the context of theological education in multilingual societies. In his review of the 'teleological core' (Nel 2005:441) of theological education over time, Nel (ibid) identifies 'hermeunetical communicative competence' as a pivotal concept:

The pastoral leader is a communicator. For this ability to communicate efficiently he or she needs hermeneutical abilities. Anyone who cannot communicate with the past, who cannot read and interpret the text of the Bible as well as the second text of society, congregation and individuals, cannot be a public pastoral leader. (pp. 457-458)

In an increasingly multilingual world and in South Africa, the communicative, language repertoire, interpretative and translation requirements of church leaders are greater than ever and would certainly impact theological education and theology as a profession. A description and analysis of the nature and relationship of multilingualism to ministry in one successful case would hopefully contribute to support church leaders and academics involved in theological education to explore ways in which to address the unresolved challenges posed by the multilingualism in integrated congregations more effectively.

\section{Clarification of concepts}

For the purpose of this article, it is necessary to define two important concepts used: multilingualism and language repertoire. Researchers agree that it is important to provide a definition of multilingualism for each study where this 
phenomenon is the focus, because it is used differently by various scholars (Kemp 2009:24); and if definitions are not stated clearly, it is impossible to compare findings across contexts (Edwards 1994:138). In this article, Kemp's (2009:15) summary of long-standing definitions of multilingualism proposed by McArthur (1992), Edwards (1994) and Vildomec (1963) is used:

A multilingual person is a person who has the ability to use three or more languages, either separately or in various degrees of code-mixing. Different languages are used for different purposes, competence in each varying according to such factors as register, occupation and education. Multilinguals may not have equal proficiency in or control over all the languages they know.

This definition is important in the context of South Africa where 'circumstantial multilingualism' or 'folk multilingualism' (Aronin \& Singleton 2012:121) is widely spread. In contexts where people acquire circumstantial multilingualism, they have to acquire additional languages as a means to survive in the society (as opposed to a context where people elect to add languages to their repertoires, usually via formal education). In South Africa, home languages are learnt at home, and home languages and English as first additional language (and Afrikaans as first or second additional language) are taught at school. Additional African languages are learnt informally in the community. The context of acquisition (the home, the school or the community) determines the nature of the proficiency of the languages in the repertoires of their speakers.

Elsewhere Coetzee-Van Rooy (2012:89), defines language repertoire as 'the range of languages known from which multilingual people draw the resources they need to communicate in multilingual societies'. This is a well-known definition build upon the conceptualisations of Fought (2006:21) and Banda (2009:6). It is also widely accepted that people with multilingual language repertoires would display different levels of proficiency and knowledge for the range of languages included in their language repertoires and that these levels of proficiency and knowledge would be dynamic; in other words, would change over time, dependent on changes in the context (Herdina \& Jessner 2002:89-106).

In this article, I therefore aim to describe the multilingual repertoire of a church leader, and to relate his repertoire and the interaction between languages in his repertoire to his ministry. Ultimately I hope to focus on an explanation of how his multilingual repertoire acts as a resource in his profession. This case study could provide another set of information to scholars like Venter (1998) and Adams (2014) who study the use of languages in integrated, multilingual church communities in the postapartheid South Africa. Case studies like these could provide examples of how the use of indigenous languages could be enhanced in integrated, multilingual congregations.

\section{Methodology}

Traditionally, large scale language repertoire studies are conducted via the use of questionnaires that focus on issues such as the number of languages known by participants, the factors that influence the learning and current use of languages and attitudes of respondents towards the languages in their language repertoires. For the purpose of the research question of this article, a questionnaire would capture basic language repertoire information, but it would not render information about the participant's views of how his multilingual repertoire supports his ministry; and why he thinks this is the case. Interviews are traditionally regarded as the best research instruments to capture such qualitative information (Henning 2004:50-80). The interview questions included questions about the language repertoire and history of the participant, as well as his views on how the languages in his repertoire aid his ministry.

The researcher conducted the interview with the participant in Afrikaans on 10 April 2013 and it was audio-recorded with the permission of the participant who also gave informed consent to participate in the project. The interview lasted one hour and fifty-five minutes. The interview was transcribed by an experienced research assistant and resulted in 22700 words (including the words spoken by the interviewer and the interview). The transcription was quality assured by the researcher. The researcher listened to the audio recording of the interview with the transcription and made minor corrections where the transcriber could not ascertain words that were unclear.

In this article I follow Henning's (2004:101-140) approach to analyse and interpret the interview data captured. This approach is part of the broader category of content analysis methods where the content of the interview is coded to mark relevant themes as they occur in the interview. The codes are then clustered into broader categories if necessary. Via the coding and the clustering of codes into broader categories identified in the interview transcripts, the themes relevant to the research question of the study emerge. All codes were tagged in the computer file of the transcription and then analysed with the help of WordSmith tools (version 5). Word lists and concordances for all tagged codes in the speech of the participant were drawn in WordSmith. The researcher interpreted the codes and clustered codes into broader themes that are presented as findings in the article and then subsequently presented the information as a narrative argument with evidence from the interview within the broader framework of the language repertoire studies. These findings are situated within the broader body of knowledge related to the multilingual repertoire of this church leader and how his repertoire acts as a resource in his ministry.

A case study is traditionally conducted 'because the researcher suspects that there is something to be unraveled in the case' (Henning 2004:32). It involves the study of a phenomenon as a 'bounded system' (ibid:32) with the aim to 'see patterns, relationships and the dynamic that warrants the inquiry' (ibid:32). The case study approach is therefore ideal to address the research question of this article: How do the patterns that emerge from the multilingual repertoire of 
this participant relate to his profession as a church leader? Ultimately, the findings would contribute to provide specific ways to address the unresolved challenges that emerge as a result of the multilingualism prevalent in integrated churches.

\section{Findings}

In this section, the general description of the language repertoire of the participant as well as an analysis of the interview data that reflect on the interaction between multilingualism and the ministry of this participant is provided.

\section{Description of the language repertoire of the participant}

Typical descriptions of language repertoires include a list of the languages known by the participant (also with reference to how many languages are included in the repertoire) and a description of how and why he or she learnt these languages. The latter descriptions allow one to determine the functions that the languages are used for as well as the types of language skills developed in the languages.

The participant in this study listed 12 languages as part of his repertoire: Afrikaans, English, Southern Sotho, Northern Sotho, Tswana, Lozi, Zulu, Xhosa, Dutch, German, biblical Hebrew and biblical Greek. In this interview, the participant explained in some detail how and why he learnt Southern Sotho, Afrikaans, English, Dutch, German, biblical Hebrew and biblical Greek.

One of the surprising findings is that Southern Sotho is the language learnt first by the participant; even before he learnt Afrikaans. He explained in detail how, from whom and why he learnt Southern Sotho and Afrikaans:

[1] Wat gebeur het is, ek het 'n Sotho-maatjie gehad. 'n Bietjie ouer as ek wat saam met my gespeel het op die plaas, van kleins af. En dan was daar ' $n$ vrou wat nou maar omgesien het na ons en 'n ogie gehou het oor ons, want mamma het gewerk in die dorp en pappa was maar altyd daar op die plaas rond met die werkers, wat ook al, wat hulle gedoen het. So ek is deur die dag, heeldag in sy geselskap gewees. Ek het heeldag sy taal gehoor en die vrou wat na my omgesien het se taal gehoor. En net vanaand en môreoggend is ek in Afrikaanse taal. So dit is volgens my moeder se oordrag is dit die eerste taal wat ek gepraat het ... En Afrikaans het dan nou agterna gekom. [What happened is, I had a Sotho friend. A bit older than I who played with me on the farm, since we were little. And then there was a woman who had to take care of us and look after us, because mom worked in town and dad was on the farm with the workers, whatever they were doing. So during the day, he and I were companions. I heard his language the whole day and I heard the language of the woman who took care of us. And only in the evening and in the morning I was in the Afrikaans language. So according to my mother's recollections it (Southern Sotho) is the first language that I spoke ... And Afrikaans came after (Southern Sotho).]

He explained that he never had formal education in reading and writing Southern Sotho. He is of the opinion that the ability to read and write in Southern Sotho came naturally to him. He related four events that helped him to learn how to read and write in Southern Sotho. First of all, he started to correspond with one of his childhood Southern Sotho friends when he went to the army (air force) after he completed matric:

[2] En toe na matriek, toe ek nou weg is weermag toe, het J vir my pa begin werk, want toe is hy ook nou klaar met skool. En toe het ek en hy begin korrespondeer en vir mekaar begin skryf ... En toe kom $[e k]$ agter, maar dit lyk so vir my of hy nie altyd heeltemal reg skryf nie. Ek weet nie hoekom nie. Ek het net die natuurlike aanvoeling gehad daarvoor ... Maar in elk geval, dit is waar ek begin het met die lees en skryf, dit is wat ek en hy korrespondeer het met briewe saam. [And after matric, when I went off to the army, J started to work for my father, because he was also finished with school. And then he and I started to correspond with each other... And then I realised, but it does not seem as if he always writes correctly. I don't know why. I had a natural ability for it ... But in any case, that is where I started to read and write, it was when he and I corresponded via our letters.]

Secondly, when his calling grew stronger, he started to read the Southern Sotho Bible. During this process, he realised that his intuition about J's incorrect writing of Southern Sotho was correct:

[3] En toe op 'n stadium toe ek nou bediening se kant toe begin gaan, het ek die Sotho-Bybel gevat en begin lees en toe kom ek agter maar ek was reg gewees daardie tyd. So ek weet nie of dit moontlik is dat ' $n$ mens so ' $n$ natuurlike aanvoeling kan hê daarvoor nie. [And then, at some point when I started to move closer to my calling, I took Southern Sotho Bible and started to read and then I realised that I was right at that time. So I do not know if it is possible that one could have such a natural ability for it.)]

Thirdly, he was asked by the principal of a small school in his community to teach Southern Sotho to the Grade 4 to 7 pupils in the school.

[4] En op 'n sekere stadium het 'n skoolfhoof my gevra, sy Sotho onderwyseres gaan weg. Maar dit is nou al hier in die tweeduisends, en so Sotho is nie verpligtend gewees nie. Maar hy wou graag sy kinders dit laat neem, om hulle meer toe te rus. Hy wou graag gehad het sy kinders moet beter toegerus wees as ander skole se kinders. So toe vra hy vir my of ek nie wil inkom en kom help nie. Toe het ek nou maar gaan bid daaroor en toe het ek hom, ek het vir so twee jaar Sotho aangebied ja, van Graad vier tot sewe. [And at some point a principal asked me, his Southern Sotho teacher was going away. But it was somewhere in the 2000s, and Southern Sotho was not compulsory. He was keen that his pupils should learn Southern Sotho. He wanted his kids to be better prepared than kids from other schools. So he asked me if I did not want to come and help. I prayed about the matter and I went, I taught Southern Sotho for about two years to kids in Grades four to seven.]

The fourth event that the participant mentions that strengthened his learning of Southern Sotho, was his ministry:

[5] En toe later nou natuurlik toe ek nou in die bediening in is, het ek hoofsaaklik nog steeds maar Sotho, van die begin af maar hoofsaaklik Sotho bedien. So ek het my Sotho-Bybel gehad en ek het maar daarmee aangegaan. [And later when I went into the ministry, I mainly continued in Southern Sotho, from the start I mainly ministered in Southern Sotho. So I had my Southern Sotho Bible and I simply continued with it.] 
The link between the participant's ministry and Southern Sotho and the other language he knows will be explored in more detail in the next section. For the purpose of the description of his language repertoire, it is important to note that there was a time in the participant's life when he feared that he was losing his Southern Sotho. He explains that when he was about 21 years old, he was stationed in Pretoria and Pietersburg when he did his compulsory army consignment. In this environment, he did not have contact with Southern Sotho speakers. When he returned home during weekends, he started to note that his vocabulary in Southern Sotho was not active enough anymore. This worried him, and again, he found a strategy (which, according to him, was one that God gave him) with which to maintain his Southern Sotho. He describes this as follows:

[6] Een en twintig, daar somewhere. En, want hoe ek dit agtergekom het, is al meer en meer as ek by die huis is en ek praat met mense daarso dan is daar woorde wat ontbreek. Ek kan nie onthou wat die woord is nie. So ek moet nou vra: 'Wat noem 'n mens nou weer hierdie ding, wat is hierdie woord?' dan moet hulle verduidelik. En toe besef ek maar my Sotho is besig om dood te gaan. Ek is besig om dit te verloor. En ek wou nie dit verloor nie, dit was vir my kosbaar gewees. Nie dat ek regtig 'n gebruik gehad het daarvoor op daardie stadium nie, maar dit was vir my kosbaar ek wou dit nie verloor nie ... Want dit was vir my iets unieks gewees. En veral die manier wat ek geseënd was, wat ek gebless was daarmee om dit te kan so vlot en die Sotho sê 'jou tong lê plat' ... En die Here openbaar toe aan my ek moet sover as moontlik moet ek in Sotho dink. En ek moet baie kere wanneer ek alleen is, well obviously moet ek in Sotho praat sodat my tong, my spraakorgane gewoond kan bly aan die uitsprake en, want dit is rondings en dit is, dit is 'n klankryke taal, dit is 'n pragtige taal ... Ja dit was vir my regtig rooi ligte wat aangekom het ... En toe het ek sover moontlik het ek in Sotho gedink. [Twenty-one, there somewhere. And, because how I realised it, is that more and more, when I went home and I talked to people there, then there are words that are missing. I cannot remember what the word is. So I had to ask: 'What does one call this thing, what is that word?' and then they must explain. And then I realised that my Sotho is starting to die. I am busy losing it. And I did not want to lose it, it was precious to me. Not that I had any use for Sotho at that stage, but it was precious to me and I did not want to lose it ... Because it was something unique to me. And especially the way in which I was blessed to be so fluent at it. The Sotho's say 'your tongue lies flat' ... And God then revealed it to me that I must think in Sotho as far as possible. And I must many times when I am alone, well obviously, I have to speak Sotho so that my tongue, my speech organs are used to the pronunciation, because it is the rounding, it is a sound rich language, it is a beautiful language ... Yes, there were red lights that started to flicker (flash)... And then I started to think in Sotho as far as possible.]

His metalinguistic awareness warned him that his abilities in Southern Sotho were decreasing and, as is akin in his life, God assisted him to find a strategy to keep his beloved Southern Sotho going. This link between his calling and his ability in languages will be discussed more fully in the next section.

The participant did have English teaching at school, but he does not seem to remember learning much English at school. He recollects how strict his standard 6 (Grade 8) English teacher was and that his strategy to survive was to simply fall silent in her classes:

[7] Ja, in standerd ses het ons 'n Juffrou L gehad, ongetroude juffrou wat nou kom begin skoolhou het. En sy was baie streng daarop gewees, jy mag nie 'n ander taal gepraat het in haar klas as Engels nie. So die maklikste en die beste is, sluit toe en gooi weg die sleutel ... Want op daardie stadium kon ek just about net sê 'yes and no', en nog iets anders wat 'n mens nie in goeie geselskap sê nie. [Yes, in standard six we had a teacher L, unmarried teacher who started to teach. And she was very strict, you may not speak another language in her class than English. So the easiest and best is, lock [your mouth] and throw away the key ... Because at that stage I could only say 'yes and no' and something else which one should not say in discussion with decent people.]

In his opinion, the army was instrumental in him learning English:

[8] Nee wat daar is nie vir my 'n probleem [met Engels] nie. Ek dink nogal die weermag het' $n$ groot aandeel daarin gehad. Want daarso, daar was maar 'n klomp souties saam met ons gewees ... En een van hierdie soutgeeste het ' $n$ vriend van my geword. So ek het regtig redelik, redelik goed Engels geleer praat by hom. En uitsprake en goed, so rukkie terug het ek komplimente gekry van verskillende mense af, verskillende tye, dat my Engelse uitspraak is baie-baie goed. So dit was nogal vir my 'n riem onder die hart gewees. Weereens, maar weer wat 'n mens die Here se hand daarin sien. In die voorbereidingsproses. [No, I have no problem with English. I think the army contributed greatly to me (learning English). There, there we were placed with a lot of 'Souties' ... One of these 'Soutie souls' became a friend of mine. So I really learnt English very well from him. And pronunciation and stuff, so much so that a while ago I received compliments from a variety of people, at various times, that my English pronunciation is really very good. So that was a source of comfort to me. Again, again one sees the hand of God in this. In the preparation process.]

He also explained that after the army, he upheld his English via the help of a bilingual friend of his children who was English-dominant. He explicitly decided to communicate with this friend in English to afford him an opportunity to 'keep his English going':

[9] En toe na die weermag toe nou, na die lugmag, het my kinders 'n Engelse vriend gehad. Hy was tweetalig, maar hy was eintlik maar Engels. So ek het maar, wanneer ek en hy kommunikeer, het ek maar meer Engels probeer praat met hom om my Engels aan die gang te hou. [And after the army, the air force, my children had an English friend. He was bilingual, but he basically was English. So I, when he and I communicated, I tried to speak English with him to keep my English going.]

The story of the participant's non-learning of English at school is an indictment on his teacher and/or the type of curriculum he was exposed to. He continued to learn English (and 12 other languages) later in his life, despite his unsuccessful school education in English.

The participant learnt languages like Dutch, German, biblical Hebrew and biblical Greek during his time as student at a theological seminary. During this time he realised that his fellow students struggled to understand the Dutch textbooks they had to read, whilst he felt that he easily followed the Dutch. 
[10] Toe kom ek agter maar die ander studente kla oor hierdie Hollands wat hulle moet lees en hulle sukkel om dit te verstaan en ek kom agter maar ek vang dit sommer vinnig, dit is vir my amper tweede natuur. En toe het ek agtergekom, o ja en toe moet ons, ons moes toe nou Duits ook doen ... Ons moes Duits as vak neem. Toe kom ek agter maar ek is eintlik verskriklik lief vir tale. En daarom het ek op 'n stadium toe nou ingeskryf vir Afrikaans ook en toe het ek Afrikaans een en twee gedoen en drie het ek so halfpad gegaan en toe het die Here ' $n$ ander plan gehad met my, toe het ek hom nou maar gelos. [I then realised that the other students were complaining about the Dutch that they must read and they struggle to understand it and I realise that I understand it quickly, it is almost like second nature to me. And then I realised, o yes, and we had to take German too ... We had to take German as subject as well. Then I realised that I actually love languages. And at some point I enrolled for Afrikaans as well and I did Afrikaans one and two and three I did half way and then God had another plan with me, so I stopped Afrikaans.]

The participant's relationship with Hebrew will be discussed more fully in the next section.

The participant therefore learnt Southern Sotho first, because it was the language he was exposed to most of the time in his early childhood. He learnt it from his Southern Sotho friend and the woman who took care of them during the day. $\mathrm{He}$ learnt Afrikaans during the evening and early in the morning before his mother went to town to do her job and his father left to work on the farm. He learnt English mainly as a result of his stint as a soldier in the air force and his friendship with an English-speaking friend of the family. He learnt Dutch, German, biblical Hebrew and Greek at university and also took Afrikaans as an additional subject for two years during that time. It was at university that the participant realised how much he loved languages and that he is good at learning languages.

The interview data lead to the following conclusions related to the language repertoire of the participant:

- He reports to know 12 languages as part of his repertoire and this makes him an exceptionally gifted multilingual speaker, even by South African or African standards.

- He reports to have exceptional abilities in Southern Sotho, Afrikaans and English.

- The participant displays enhanced levels of metalinguistic awareness that lead him to monitor his abilities in the languages he knows in a natural way. When he experiences a decrease in language abilities, he is able to devise appropriate strategies to counter the decline in experienced language ability.

\section{Multilingualism in interaction with ministry}

The main aim of this article is to relate the language repertoire of this multilingual church leader to his ministry. In other words, how does this multilingual minister perceive the usefulness of his language repertoire in his ministry? A deeper understanding of the nature of his language repertoire is a starting point to consider the possible implications for theological education and language policy matters in the church domain related to integrated congregations.
The main theme that arose from the interview data was the direct relationship in the mind of this church leader between his ability to learn many languages and his calling as a church leader. He stated this relationship as follows in the interview:

[11] Die Here het vir my Skrif gegee 'n hele paar jaar terug. Openbaring, ek dink dit is Openbaring twee vers agt wat Hy sê, 'Kyk ek gee voor jou 'n geopende deur wat niemand kan sluit nie'. En ek is oortuig daarvan dat hierdie ' $n$ belofte is wat die Here vir my gegee het en dat Hy die deure vir my op so manier vir my oop maak, met hierdie taalvaardigheid wat Hy vir my gegee het. Want oral waar ek kom kry ek guns by mense. [The Lord gave me Scriptures many years ago. Revelations, I think it is Revelations two verse eight where He says, 'Look, I give you an opened door that no one would be able to close'. And I am convinced that this is a promise that the Lord gave me and that He opens doors for me in this way, with this language ability that He gave me. Because everywhere I go I receive generosity from people.]

The participant felt so strongly about this issue, that at some point in the interview he stopped and explained in a summative way that, the level of his Southern Sotho is exceptional; and how seriously he experienced this relationship between his advanced language abilities (especially in Southern Sotho) and his calling:

[12] Ek loop nie met dit te koop rond nie. Maar ek dink vir die doel waarmee ons besig is, is dit dalk nodig dat ek dit so uitdruk dat dit goed verstaanbaar is. Ek praat dit baie beter as enige normale blanke wat dit kan praat. Ek het nog net een ou raakgeloop wat dit so goed kan praat soos ek, maar die oomblik wat ons geestelike dinge begin praat, dan haak hy vas ... Ekskuus, net voor ons na die volgende vraag toe gaan, dink ek moet ek net hier afsluit deur te sê dat ek dink tog, nee ek dink nie, ek is baie oortuig daarvan in my hart, dat die Here gee mens die opleiding van reg van geboorte af om jou te bring op 'n punt waar hy jou wil hê, sodat jy in die bediening kan staan. Want elkeen van ons het ' $n$ bediening en God weet wat se job het Hy vir ons ... En die Here het geweet waar Hy my wil gebruik en daarom dat Hy toegelaat het dat dit so gebeur met my, sodat ek op hierdie vlak kan wees met Sotho. [I do not brag about this. But I think for the purpose that we are busy here, it is necessary that I express it clearly so that it is understood well. I speak this better than any normal white person can speak it. I have met one other man who can speak Sotho as well as I, but the moment we talk spiritual matters, then he is not fluent ... Please excuse me, just before we move to the next question, I think I need to just conclude here by saying that I think, no, I don't just think, I am convinced in my heart, that the Lord provides education and preparation right from one's birth to bring you to a point where He wants you, so that you could function in his service... And the Lord knew where He wanted to use me and therefore He allowed it to happen in the way it did, so that I am at this level with my Sotho.]

In another extract above, it is also clear that he ascribes his abilities to learn to speak English well also to the Lord's plan for his life, or his calling when he said: 'Weereens, maar weer wat 'n mens die Here se hand daarin sien. In die voorbereidingsproses.' [Again, again one sees the hand of God in this. In the preparation process.]

A second theme related to the multilingual abilities of this participant and his calling as a church leader that arose from the interview, was his belief that this ability positions him 
perfectly to build bridges in South Africa; and indeed that this is part of his calling. In the context of South Africa's apartheid history, the participant clearly experiences his advanced abilities in Southern Sotho and other languages as a tool to be used to build reconciliation in the country between race groups.

The evidence related to race relations in the interview also demonstrates the complexity of these issues as experienced throughout the life of the participant. On the one hand, his best friends from his childhood were Southern Sotho speaking boys on the farm. Even early in his life, he experienced tension when his white and black friends played together from time to time and his white friends misbehaved in some way towards his black friends. He related the following incident as illustration:

[13] Maar in die middag as ek by die huis kom, die swart maatjies was my maats. Ek het in die skool het ek nie eintlik maats gehad nie. As ek wel 'n maat gehad het was dit 'n mooiweers vriend. Tot hy iemand anderste kry wat hom iets beter kan. Ek was maar 'n alleenloper want ek is die enigste kind ook ... daar het soms maats kom kuier op die plaas. En dan het party van hulle het lelik geraak met die swart maatjies en dit het my gegrief ... Ja en dan het ek in my hart gevoel dat ek my eerder by die swartetjies wil skaar as by hierdie wit kind ... Ja maar dan het ek in elk geval probeer om hierdie saak op te los, want hierdie ouens gaan seerkry en dit is my pelle. As hierdie ou weg is, is dit nog steeds my pelle. Dit is die ouens met wie ek gaan speel en met wie ek gaan kommunikeer, ensovoorts, ensovoorts. So hierdie ou moet mens dalk tot 'n mate sê word nou 'n bedreiging vir hierdie verhouding wat ' $n$ mens het. En hy is op die punt om hierdie verhouding skade aan te doen. 'n Mens staan tog op vir jou vriende. [But in the afternoon when I got home, my black friends were my friends. I did not really have friends in the school. If I had a friend, it would be a 'fair weather friend'. Until he met someone else who could offer him something better. I was often on my own because I am an only child as well ... sometimes friends did come and play on the farm. And then some of them were not nice with the black friends and that pained me... Ja and then I felt in my heart that I should rather be supportive of the plight of my group of black friends than with this white child ... Ja but I in any case tried to solve the problem because these guys are going to get hurt and they are my pals. When this guy is gone, these guys are still my pals. These are the guys with whom I will play and with whom I communicate, etc., etc., etc. So this guy one could then say to some extent now becomes a threat to the relationship one has. He is on the verge of harming this relationship. A person should stand up for one's friends.]

He also explained that he grew up in a so-called right-wing white Afrikaans home as a child and later on in his life, he studied Theology at a conservative seminary. The participant is quite honest that he needed a Damascus event in his life before he could take up this calling as a bridge-builder. $\mathrm{He}$ explained it as follows in the interview:

[14] Tussen daardie gedeeltes waar ek aansoek gedoen het vir die pos en somewhere êrens agtertoe het daar 'n draaipunt gekom in my lewe en die Here het my net omgedop. Ek sien myself ook as 'n tipe van 'n Paulus ... Op daardie Damaskuspad gewees en die Here het my net so omgedop. Waar ek 'n vervolger was en nou is ek 'n navolger. Ek is nou meer, ek werk juis onder hierdie ouens, ek vang juis hierdie ouens, wat ek eers met ' $n$ passie. Ja, ek het hulle nooit gehaat nie, ek probeer net verduidelik ... Ek het geglo hy het sy plek, ek het my plek, blah-blah-blah langstories. [Between these dates where I applied for this position and somewhere after that, I reached a turning point in my life and the Lord simply turned me around. I see myself also as a type of Paul ... On that Damascus road and the Lord simply turned me around. Once I was a persecutor and now I am a follower. I am now more, I work specifically with these people, I catch these people, that I once with a passion. Ja, I did not hate them, I am trying to explain ... I believed he had his place, I had my place, blah-blah-blah long stories.]

He clearly believed that reconciliation in South Africa has not yet started properly when he said:

[15] Ek weet nie of hierdie brug enigsins begin bou is eerstens nie. [I do not know if this bridge at all, has been built in the first place.]

As part of his calling, he saw himself as a bridge-builder, especially between races in South Africa. He, for example related the following experience:

[16] En baie mense het al vir my gesê, daar is al geprofeteer ook oor my, dat ek hierdie brugbouer is tussen die verskillende, tussen hierdie kulture. Veral tussen die wit en swart kultuur. Nou die dag het iemand weer, ek het gaan koffie drink sommer net by 'n kollega van my. Ag, ons is goeie vriende eintlik. Dit is lekker om so boeta te hê. Om sommer te kan uitvat, sommer net bietjie gaan koffie drink daar by hom. En ons bid toe nou saam en toe ons klaar gebid het, toe sit hy so bietjie stil en hy knik sy kop so. Hy sê vir my, 'Weet jy my boeta, terwyl jy so bid wys die Here net vir my hierdie, Hy gee my hierdie visioen en Hy wys net vir my jy is hierdie enorme brugbouer. En ek persoonlik, na hierdie visioen, dink ek jy is besig om jou tyd te mors. Jy moet na groot instansies toe gaan, Rhema of van hierdie groot denominasies toe. Want dit is wat jy moet gaan doen. Jy moet hierdie bruê gaan bou.' [And many people had told me, it had been prophesised about me, that I am this bridge-builder between different, between these cultures. Especially between the white and black culture. Just the other day, I had coffee with a colleague of mine. Ag, we are good friends. It is nice to have such a brother. To sommer go out together to have coffee with him. And we prayed together and when we finished with prayer, he sat quietly for a moment and he nodded his head. And then he said to me, 'You know my brother, while you were praying, God made me see a vision and He showed me that you are this enormous bridge-builder. And I personally, after this vision, I think you are wasting your time. You must go to the big organisations, Rhema or one of these big denominations. Because that it where you must go. You must build these bridges.'].

This part of the participant's calling resulted in him being cut off from his white community to some extent:

[17] Miskien moet ek so begin, ons ervaar baie sterk, en as ek praat van ons dan bedoel ek myself en my vrou, ons ervaar dit baie sterk dat die blanke gemeenskap ons so soort van wegstoot, uitstoot tipe van iets. Ons vriende is nog ons vriende, almal is nog vriendelik met ons en alles, maar 'n mens voel, jy ervaar net daardie, 'Jy weet julle is bietjie anders, julle is meer na die "donkergroen" se kant toe.' [Maybe I must start as follows, we experience strongly, and when I speak about us, I mean my wife and I, we experience it very strongly that the white community pushes us away, type of shuns us. Our friends are still our friends, everybody is still friendly with us and all, but one feels, you experience that, 'You know, you are a bit different, you are leaning more towards the "dark green" side.']

The third prominent theme that arose from the interview data that is related to the participant's enhanced language abilities 
and his calling, is how he uses his skill in Southern Sotho to find ways to start conversations and relationships with people that could lead to him ministering to them. He has developed an overt communicative strategy where he would talk to people in queus in public places in Southern Sotho and then he would use their surprise at him being so good at Southern Sotho as a starting point for a discussion that would quickly revert to a religious or spiritual discussion, as explained in the extract below:

[18] Ek staan nie vir ure lank in die ry nie ... Maar net as gevolg van die feit dat ek oral waar ek kom verkondig ek die evangelie. Ek begin 'n gesprek en so deur die loop van die gesprek kry ek êrenste 'n aanknopingspunt. Die Here bring net daardie punt vir my. Soms is dit, wel baie kere is dit omrede hulle vir my die vraag vra van 'waar ken jy die taal vandaan'. Nou vra ek die teenvraag weer vir hulle terug, 'maar waar ken jy dit vandaan'. 'Nee, maar ek het daarmee grootgeword'. En dan is die lekkerste om te sê 'maar dan is jy rassisties, want jy sê daardie taal behoort nie eintlik, ek behoort nie die taal magtig te wees nie'. En dan is daar mos nou ' $n$ grappie gewees. Dan begin hierdie persoon oopmaak in elk geval. 'Nee maar dit is nie so nie'. Dan sê ek 'nou maar hoekom vra jy nie hierdie ou wat voor my hier was waar ken hy dit vandaan nie'. En dit is 'n aanknopingspunt. En vandaar af dan beweeg ' $n$ mens in die Woord in. So almal ken my maar oral waar ek gaan en miskien omdat ek uitstaan soos 'n seer vinger ook. [I do not stand in queus for a long time ... But just because of the fact that I spread the Word wherever I go. I start a discussion and somewhere during the discussion I find a point to link to. The Lord just brings that starting point to me. Sometimes it is, well many times it is because they ask me the question about why I know the language so well. Then I ask a counter question, 'but where do you know the language from'. 'No, I grew up with it'. And then it is the nicest to say, 'but then you are a racist, because you say I should not know the language so well'. And then there was a joke. Then the person starts to open up in any case. 'No but it is not true'. Then I say 'so why don't you ask the guy in front of me where he knows the language from'. And it is a starting point. And from there one moves into the Word. So everyone knows me wherever I go and maybe because I am conspicuous.]

This strategy and approach used by the participant to start discussions everywhere he goes and then to move the discussion towards spiritual matters is described by the participant's wife, related by him as follows in the interview:

[19] En ek lek enige predikant om 'n gemeente so groot soos myne te hê, want daar waar ek kom, is my gemeente. Hetsy dit in ' $\mathrm{n}$ supermark by die till is, of by die veearts is, of waar ever ook al. Waar ek kom, is my gemeente, want daar is altyd 'n aanknopingspunt. My vrou sê ook vir mense wat hulle nou so begin gesels oor my ... Dan noem sy baie keer en dan sê sy 'Man, weet julle, my man is altyd besig met die evangelie. Jy sal dink hy gesels sommer net met iemand en hulle lag en hulle skerts en hulle gesels. Mens sal dink hulle gesels nou regtig lekker. Hulle doen, maar dit is lankal nie meer wêrelds nie, hy is lankal in die Bybel in met hulle.' En dit is maar [so]. [And I lick any minister to have a congregation as big as mine, because where I go, there is my congregation. It could be at the till in the supermarket, or at the vet, or wherever. Where I go, there is my congregation, because there is always a starting point. My wife says to people that talk about me... Then she often says, 'Man, you know, my husband is always busy with the Word. You would think he is simply talking to people and they laugh and make jokes and have a conversation. One would think that they are having a nice conversation. They are, but they are quickly talking about the
Bible, and long before they know it, they are not talking about worldly matters anymore.' And it is like that.]

The fourth theme that arose in relation to the enhanced language abilities of the participant and his calling is the notion that his multilingualism is a resource or a currency. The participant's multilingualism is a resource in his ministry in a very practical way. As a minister he has the ability to compare a variety of translations of the Bible in his preparation for sermons. During the interview, the participant demonstrated how he could use this ability when he explained how he did a comparison of the translations of the Bible in about 11 of the languages that he can read at some point in his life. He started this comparison because he was curious about the fact that people always criticise translations of the Bible. $\mathrm{He}$ felt that at a certain stage the criticism against the most recent Afrikaans translation was really strong and he was interested to try and see, in his opinion, which translation was correct. Whilst he was busy with this comparison, he realised that there is a difference between translation and interpretation and he tried to compare the 11 translations that he had with him that he could read to see which translator tried to achieve which purpose. During this process, he came to a shocking realisation (for him) about the old translation of the Southern Sotho Bible that he explained as follows in the interview:

[20] En toe het ek dit begin kyk en toe begin daar iets anderste my prikkel. Toe begin ek daarna kyk om te sien hoe naby aan die grondteks is hierdie vertalings ... Ek het so omtrent elf vertalings as ek reg onthou wat ek langs mekaar neergesit het en toe vergelyk ek dit met die Hebreeus en met die Grieks, met die grondteks ... En in hierdie vergelyking het ek toe nou tot hierdie verskriklike skok gekom. Dit was 'n skok gewees vir my eintlik. Hierdie bevinding van hierdie ou Sotho vertaling is die naaste aan albei grondtekste vertaal as al hierdie ander vertalings ... Daar is bitter min wat verlore gegaan het in die vertaling ... 'n Voetnota net by te voeg, want dit is reg vertaal, daar is niks fout met die woord nie maar die betekenis in konteks kan dalk verlore raak en dan kan hierdie woord se vertaling dalk heeltemal op 'n dwaalspoor ... En dit gebeur baie met die swart pastore. Meeste van hulle het nie opleiding, glad nie teologiese opleiding gehad nie ... So hulle gaan net op hierdie Sotho-teks staatmaak en dan baie van hulle gebruik dit buite konteks ook. Want hulle verstaan nie binne konteks en buite konteks nie. Hulle weet nie daarvan eers nie. [And then I started to look and something else made me curious. Then I started to see how close the original text is to these translations ... I used about 11 translations if I remember correctly that I compared with the Hebrew and the Greek, with the original text ... And in this comparison I come to the shocking realisation. It was a shock to me actually. This finding that the old Sotho translation is the text that is closest in translation to the original texts, closer than any of the other translations... Very little was lost in translation ... I need to add a footnote, because it is translated correctly, there is nothing wrong with the word, but meaning in context could be lost and then this direct translation could put people on a wrong path... And it happens with the black pastors. Many of them have no education, no theological education ... So they would just depend on the Sotho text and many of them use it out of context. Because they do not understand in and out of context. They know nothing about it.]

In another discussion with the participant that was not audio-taped, he explained to me that when he is lazy to read 
the Hebrew Bible in preparation for sermons, he uses the old Southern Sotho version instead because it provides him access to the Hebrew text with much greater ease and speed. This was an unexpected finding as it would be inconceivable that one could access Hebrew via Southern Sotho. These types of resources are available to multilingual church leaders.

The main findings from the interview data in relation to the ministry therefore are that there is evidence that the multilingual repertoire of the participant:

- is part of his general calling to become a church leader;

- is part of his additional calling to be a bridge-builder between white and black people in his community;

- enables him to craft a specific personal communication strategy where he uses his multilingual abilities to start conversations with all people, that provide an entrance point for him to start relationships, so that he could invite them into his ministry; and

- is a valuable resource that enables him to minister effectively.

\section{Discussion, implications and conclusion}

In this section, the findings reported in the previous section will be embedded within the broader body of knowledge related to multilingualism in the world, in South Africa and related to the profession of church leader in this context; and some implications and conclusions will be offered.

In terms of the language repertoire of the participant, it is important to note that his multilingualism is exceptional in the broader South African context, but even more so in the context of Afrikaans-speaking South Africans. Claims about the uniqueness of African multilingualism (in other words, the ability of speakers of African home languages to know a larger-than-usual amount of additional languages) are wellknown. Scholars like Brann (1989), Makoni and Meinhof (2004), and Banda (2009) have described the differences between European and African multilingualism at the individual and societal levels in detail. In contrast to African multilingualism, descendants of European settlers in Africa are not well-known for adding indigenous languages to their repertoire (Coetzee-Van Rooy 2014; West 2009:37, 43). A notable exception to this is the case of missionaries who are well-known for the efforts to learn indigenous languages and who often contributed to the codification and standardisation of indigenous languages (Doke 1939; 1959; Longmore 1962; Comaroff \& Comaroff 1986; Sieberhagen 2004; De Gruchy 2009; West 2009; Beckner 2013).

In research conducted in the region where the participant lives and works, it was found over a period of 10 years in at least two different language attitude and repertoire studies, that African home language users know an average of four languages (Coetzee-Van Rooy 2000; 2012). This is not the same for the Afrikaans-speaking participants in the region. They display a distinct bilingual Afrikaans-English repertoire (Coetzee-Van Rooy 2000; 2013). The participant is a descendent of European settlers, yet, he displays a unique language repertoire that goes beyond AfrikaansEnglish bilingualism. He has deep knowledge of Afrikaans and Southern Sotho (which he regards as his strongest languages) and has added English to his repertoire. He also has knowledge of various other African languages, and has learnt German and Dutch, and biblical languages like Hebrew and Greek. In a world and a country where multilingualism is on the increase, the participant is ideally positioned to engage in a career that holds high demands for language and communication abilities (like ministry) especially in this region where Southern Sotho, Afrikaans and English are dominant languages (Stats SA 2011).

When this exceptional multilingual repertoire is related to his profession (ministry), it is clear that in his opinion it plays a central role in his ministry. He, first of all, experiences his gift of learning languages as God's way of preparing him for his calling as a church leader, and as a bridge-builder across races in South Africa. He devised a personal communication strategy to perform his job by fundamentally using his advanced abilities in Southern Sotho as a starting point for discussion. Once he has hooked a conversation partner who realises that his abilities in Southern Sotho are exceptional for a white South African, he always uses the conversation to invite people into his ministry.

In the theoretical framework of Bourdieu (1991:66), languages hold 'symbolic power' or 'symbolic capital' (Coupland 2013:15). In essence, the symbolic power of a language refers to the "power of language users ... to "do things with words"' (Kramsch 2009:8). In the analysis presented in this article, the participant experiences the value or currency or symbolic power of his abilities in Southern Sotho (and his multilingualism in general), in two ways. First of all, his ability in Southern Sotho assists him in starting conversations with people he would like to invite into his ministry. Secondly, it is a valuable tool in his reading of the original Bible texts where he realised that he could access the Hebrew version via the old Southern Sotho translation which, in his opinion, is a close-to-literal translation of the original Hebrew text. This perception by the participant is confirmed by scholars like Naudé and Makutoane $(2006: 723,728)$, who refer to the older Southern Sotho Bible as 'the product of the word for word approach to translation' (cf. also Naudé \& Miller-Naudé 2011:321).

One of the implications flowing from this case study, is that it is possible for a church leader to activate multilingualism as an advantage in an integrated congregation. Even more importantly, this case study confirms Venter's (1998:34) finding that church leadership is the one factor that has the potential to enhance multilingual practices in integrated congregations. When church leaders are able and willing to expand the use of indigenous languages in their ministry, they will find effective strategies to do so; even when the 'hegemony of English' is present, as is illustrated earlier in this case study. During the interview, the participant acknowledges the complexity of working in a multicultural and multilingual congregation. 
Amongst other things, students in the congregation sometimes do not want ministry in Southern Sotho. This is expressed as follows in the interview:

[21] Ja kyk, ons gemeente is multikultureel en multitaal. Die studente, die tyd toe ons hier in die ouditorium byeengekom het, het hulle gekla en vir my gevra, 'Pastoor, asseblief moenie in Sotho preek nie, want jou Sotho is te hoog, ons verstaan jou nie' $^{\prime} .$. En dan is daar weer die ander probleem van dit is mos 'n mengelmoes, dit is ' $n$ vrugteslaaikelkie wat hier is. So daar is Xhosa, Zoeloes, Venda's wat ook al wat in elk geval nie Sotho verstaan nie. So dit is hoekom ons maar multitalig ook, Engels en Sotho doen. Maar ons het nou onlangs, het ons toe nou besluit ons gaan dit, die skaal 'n bietjie swaai dat die Sotho meer word en die Engels aansienlik minder. [Ja see, our congregation is multicultural and multilingual. The students, at the time when we met here in the auditorium, they complained and they asked me, 'Pastor, please do not preach in Sotho, because your Sotho is too high, we do not understand you'... And then there is the other problem of the mixture, it is a fruit salad here. So there is Xhosa, Zulus, Venda's who do not understand Sotho in any case. So that is why we do it multilingually, English and Sotho. But we recently, we decided that we want to tip the balance a bit to increase the use of Sotho and to decrease the use of English markedly.]

When the church leader is not able and not willing to engage with the complexities of multilingualism (as illustrated), integrated congregations will continue to revert to monolingual English services, as reported by Venter (1998) and Adams (2014).

The attitude of church leaders towards multilingualism holds pertinent implications for the language policy implemented in integrated churches. The willingness of church leaders to use African languages in church services is akin to Desai's (2010) proposal for language-in-education policy in South Africa:

The essence of the proposition is that unless language-in-education-policy decisions are top-down in South Africa, the legacies of the past will continue in the form of mainly English medium instruction, despite progressive policies which encourage the use of mother tongue in education. (p. 103)

The same seems to be true for language use in the church. Unless church leaders drive decisions about the use of African languages in church services, English will increasingly become the language of religion in South Africa. In an multilingual world and South Africa, we need more multilingual church leaders who are able and willing to engage with the challenges of multilingual congregations and who can coin strategies that would enable the use of African languages in integrated congregations.

Discussions of multilingualism in South Africa are increasingly accompanied by a growing disappointment amongst language policy and planning scholars (Du Plessis 2000; Beukes 2009; Webb 2009). The advanced multilingual arrangements documented in the Constitution of South Africa and captured in language policies of institutions like schools and universities did not result in the widespread use of African languages in high-status functions.
However, there is some recent evidence that the use of African languages in the context of the church support the maintenance of skills like reading and writing. A participant (participant S, interviewed in 2012) in another language repertoire study in the Vaal Triangle region (Coetzee-Van Rooy 2012) reported the following about her choice to use Southern Sotho as part of her confirmation in her church:

Normally at my church they ... when you get confirmed, it's most of the classes you go to they are in Sotho. But because of modern classes and schools they would let us study in English but then, I just chose to because I was like, yeah it's my choice to at least be able to write some of my own language. And, and, and have the spelling be correct. So yeah, that's the reason I decided to turn to Sotho.

In a context where there is historical and recent evidence that the church could play a supportive role in raising the status of indigenous languages, the use of African languages in multilingual arrangements in integrated churches could provide a site for the advancement of the status of African languages. This position holds important implications for theological education. We need more multilingual church leaders who are trained to serve a multilingual world. The theological education of these church leaders would then also have to include some training in relevant African languages and in the principles of managing language diversity to enhance comprehension in general.

In conclusion, I hope that this case study would contribute in some way to motivate the inclusion of this topic in future theological education. Secondly, I hope that future church leaders who are more multilingual and who understand how to use multilingualism for effective communication in their congregations would have an impact on the implementation of South Africa's multilingual language policy in this important domain.

Despite the insights gained via this case study, there are limitations that should be mentioned, particularly as these provide directions for future studies of this nature. One of the most obvious limitations of the study is its dependence on a lengthy interview with only one participant. Although it is an appropriate method for an exploratory study of this nature, future studies that aim to investigate broader trends would need to include more participants. A second limitation pointed out by a helpful reviewer of the article, is that the study did not enable direct descriptions of the strategies used by this multilingual minister that advances the effectivity and efficiency of his ministry. Future studies should attempt to observe these strategies in action by conducting analyses of the code-switching, code-mixing, and gliding between registers and varieties of the languages used by multilingual ministers to strengthen their ministry. These descriptions should be complemented by reception and/or attitude surveys to ascertain how these strategies are received by members of the congregation. These sociolinguistic mechanisms should be related more directly to elements of ministry before one could use these findings comprehensively in theological education. Herdina and Jessner (2002:152) state that, in 
general, 'research on multilingualism is still in its infancy and most of the work still lies ahead'. This impression is also true for the study of multilingualism in South Africa and how it relates to successful ministry in the post-1994 church.

\section{Acknowledgements}

The data collected for this study was funded by an annual National Research Foundation (NRF) grant that I receive as rated researcher. The NRF is thanked for their support to rated researchers in this way. The opinions, findings, conclusions, recommendations expressed are my own and not necessarily those of the NRF.

I need to thank the participant who was willing to be interviewed and who provided informed consent that I may use the interview data to describe his exceptional language repertoire and try and understand how it relates to his calling. Without him, this article would not have been possible.

I need to say thank you to Bertus van Rooy who was willing to read an earlier draft of the article and whose comments improved the article markedly. Again, remaining errors are my own.

With this contribution, I would like to celebrate the dedication and lifelong commitment to excellent biblical Hebrew teaching and research on ancient texts of my father-in-law. I hope that he finds the unexpected link forged between Hebrew and Southern Sotho in the multilingual repertoire of the participant of this study surprising and encouraging.

Furthermore, I would like to dedicate this article to multilingual ministers in my immediate circle like Prof. J.A. (Koos) van Rooy and Dr M.P. (Pieter) Kruger. Like the participant in this article, their exceptional language abilities were related closely to their callings as ministers and opponents of racism. As a struggling learner of Southern Sotho and loyal South African, my admiration for their language learning and bridge-building efforts in a complex South African society is boundless. Similarly, I admire colleagues like Prof. Christopher Rabali who made Afrikaans his own.

\section{Competing interests}

The author declares that she has no financial or personal relationship(s) that may have inappropriately influenced her in writing this article.

\section{References}

Adams, T., 2014, 'English as a language of religion in the black Pentecostal church', Paper presented at the annual joint Conference of the Linguistics Society of Southern Africa (LSSA) / Southern African Applied Linguistics Association (SAALA) / South African Association for Language Teachers (SAALT) at the University of the Witwatersrand in Johannesburg on 27 June 2014

Alexander, N., 1989, Language policy and national unity in South Africa/Azania, Buchu Books, Seapoint.

Aronin, L. \& Singleton, D., 2008, 'Multilingualism as a new linguistic dispensation', International Journal of Multilingualism 5(1), 1-16.

Aronin, L. \& Singleton, D., 2012, Multilingualism, John Benjamins, Amsterdam.
Banda, F., 2009, 'Critical perspectives on language planning and policy in Africa: Accounting for the notion of multilingualism', Stellenbosch Papers in Linguistics Accounting for
(SPIL) 38, 1-11.

Beckner, W.B., 2013, 'Eugene Casalis and the French mission to Basutoland (1833-1856)', Workshop paper \#2. 2013 Association of Professors of Mission (APM) Annual meeting, Wheaton II, viewed 11 July 2014, from http://place. asburyseminary.edu/firstfruitspapers/19/

Beukes, A-M., 2009, 'Language policy incongruity and African languages in postapartheid South Africa', Language Matters 40(1), 35-55.

Bourdieu, P., 1991, Language and symbolic power, Harvard University Press, Cambridge. Brann, C.M.B., 1989, 'The terminology of Babel - a suggestion', Journal of West African Language 19(2), 125-127.

Coetzee-Van Rooy, A.S., 2000, 'The influence of cultural identity and acquisition planning for English as a second language in South Africa', Unpublished PhD thesis, PU for CHE, Potchefstroom.

Coetzee-Van Rooy, A.S., 2012, 'Flourishing functional multilingualism: Evidence from language repertoires in the Vaal Triangle region', International Journal of the Sociology of Language 2012(218), 87-119.

Coetzee-Van Rooy, A.S., 2013, 'Afrikaans in contact with English: Endangered language or case of exceptional bilingualism?' International Journal of the Sociology of Language, 2013(224), 179-207.

Coetzee-Van Rooy, A.S., 2014, 'Explaining the ordinary magic of stable African multilingualism in the Vaal Triangle region in South Africa', Journal of Multilingual and Multicultural Development, 35(2), 121-138.

Comaroff, J. \& Comaroff, J., 1986, 'Christianity and colonialism in South Africa', American Ethnologist 13(1), 1-22.

Coupland, N., 2013, The handbook of language and globalization, Wiley-Blackwell, Chichester.

De Gruchy, S., 2009., 'Reversing the biblical tide: What Kuruman teaches London about mission in a post-colonial era', Acta Theologica 29, Supplementum 12, 48-62.

Desai, Z., 2010, 'Laissez-faire approaches to language in education policy do not work in South Africa', in Z. Desai, M. Qorro, B. Brock-Utne (eds.), 2010, Educational challenges in multilingual societies: LOITASA phase two research, pp. 102-112, African Minds, Cape Town.

Deumert, A., 2010, 'Tracking the demographics of (urban) language shift - an analysis of the South African census data', Journal of Multilingual and Multicultura Development 31(1), 13-35.

Doke, C.M., 1939, 'European and Bantu languages in South Africa', Africa: Journal of the International African Institute 12(3), 308-319.

Doke, C.M., 1959, 'Bantu language pioneers of the nineteenth century', African Studies 18(1), 1-27.

Du Plessis, T., 2000, 'South Africa: From two to eleven official languages', in K. Deprez \& T. du Plessis (eds.), 2010, Multilingualism and Government, pp. 95-110, Van Schaik, Pretoria.

Dyers, C., 2008a, 'Language shift or maintenance? Factors determining the use of Afrikaans among some township youth in South Africa', Stellenbosch Papers in Linguistics (SPIL) 38, 49-72.

Dyers, C., 2008b, 'Truncated multilingualism or language shift? An examination of language use in intimate domains in a new non-racial working class township in South Africa', Journal of Multilingual and Multicultural Development 29(2), 110-126.

Edwards, J., 1994, Multilingualism, Routledge, Clevedon.

Fought, C., 2006, Language and ethnicity, Cambridge University Press, Cambridge.

Henning, E., 2004, Finding your way in qualitative research, Van Schaik, Pretoria.

Herdina, P. \& Jessner, U., 2002, A dynamic model of multilingualism: Perspectives of changes in psycholinguistics, multilingual matters, Multilingual Matters, Clevedon.

Kemp, C., 2009, 'Defining multilingualism', in L. Aronin \& B. Hufeisen (eds.), The exploration of multilingualism, pp. 11-26, John Benjamins, Amsterdam.

Kramsch, C., 2009, The multilingual subject, Oxford University Press, Oxford.

Longmore, L., 1962, 'The future of the Bantu languages', African Affairs 61(243), 158-162.

Makoni, S. \& Meinhof, U., 2004, 'Western perspectives in applied linguistics in Africa', AILA Review 17(1), 77-104.

McArthur, T. (ed.), 1992, The Oxford companion to the English language, Oxford University Press, Oxford.

Naudé, J. \& Makutoane, X., 2006, 'Reanimating orality: The case for a new Bible translation in Southern Sotho', Old Testament Essays 19(2), 723-738.

Naudé, J.A. \& Miller-Naudé, C.L., 2011, 'Colonial and postcolonial encounters with the indigenous: The case of religious translation in Africa', Southern African Linguistics and Applied Language Studies 29(3), 313-326.

Ndlangamandla, S.C., 2010, '(Unofficial) multilingualism in desegregated schools: Learners' use of and views towards African languages', Southern African Linguistics and Applied Language Studies 28(1), 61-73.

Nel, M., 2005, 'Public pastoral leaders: The purpose of theological training', In die Skriflig 39(3), 441-462.

Pennycook, A., 2005, 'The modern mission: The language effects of Christianity', Journal of Language, Identity \& Education 4(2), 137-155.

Prah, K.K., 2010, 'Multilingualism in urban Africa: Bane or blessing', Journal of Multicultural Discourses 5(2), 169-182.

Schneider, E.W., 2007, Postcolonial Englishes: Varieties around the world, Cambridge University Press, Cambridge. 
Sieberhagen, X., 2004, 'Understanding the role the Bible Society of South Africa played in the development of missions in South Africa, Verbum et ecclesia 25(2), played in 6760 .

Slabbert, S. \& Finlayson, R., 2000, “"I'm a cleva!": The linguistic makeup of identity in a South African urban environment', International Journal for the Sociology of Language 2000(144), 119-135.

Stats SA, 2011, South African population census, community profiles, Statistics South Africa, Pretoria, viewed 06 Feb. 2013, from http://mobi.statssa.gov.za/census/ First\%20Language.html
Venter, D., 1998, 'Silencing Babel? Language preference in voluntary associations Evidence from multicultural congregations', Society in Transition 29(1-2), 22-39. Vildomec, V., 1963, Multilingualism, Sythoff, Leiden.

Webb, V., 2009, 'Multilingualism in South Africa: The challenge to below', Language Matters 40(2), 190-204.

West, G., 2009, 'The beginning of African biblical interpretation: The Bible among the Batlaping', Acta Theologiae Supplement 12, 33-47. 